\title{
The Discourses of Identity in Hellenistic Erythrai: Institutions, Rhetoric, Honour and Reciprocity
}

\author{
Peter Liddel \\ Senior Lecturer in Ancient History, University of Manchester, Manchester, UK \\ peter.liddel@manchester.ac.uk
}

\begin{abstract}
Recent research in the field of New Institutionalist analysis has developed the view that institutions are grounded not only upon authoritative rules but also upon accepted practices and narratives. In this paper I am interested in the ways in which honorific practices and accounts of identity set out in ancient Greek inscriptions contribute towards the persistence of polis institutions in the Hellenistic period. A diachronic survey of Erythraian inscriptions of the classical and Hellenistic periods gives an impression of the adaptation and proliferation of forms of discourse established in the classical period. It demonstrates the ongoing prominence of the rhetoric of identity in conversations that went on not only between peer polities and within real or imagined kinship groups but also in negotiations between powerful and weak state entities and in inward-facing discourses on euergetism.
\end{abstract}

\section{Keywords}

identity - rhetoric - euergetism - institutionalism - reciprocity - honours eunoia - Erythrai

In a recent and important monograph, M. Ehala argues that identities (both collectively and individual) can be viewed as a set of performative 'signs'

1 I am grateful to the organisers of the 2017 Kraków conference and especially Jakub Filonik for giving me the opportunity to present a paper on this theme, for their warm hospitality and for their helpful comments on this paper. I owe thanks to Madalina Dana for inviting me

(C) PETER LIDDEL, 2021 | DOI:10.1163/20512996-12340309

This is an open access article distributed under the terms of the COG BY 4 odicense. Brill, com04/26/2023 11:53:50AM 
and can therefore be fruitfully explored through the study of their expression in language and communication. ${ }^{2}$ What makes language so important to the study of identity is that it is performed by individuals but it is also a key form of collective expression. Such perspectives will not surprise historians of the ancient world, who have long taken the view that identity can be studied through investigation of language, literary traditions and the remains of material culture; they have realised the complexity and fluidity of identity as a social construction. ${ }^{3}$ In this paper, my methodology will be to use the language of epigraphical publication to explore what practices (primarily, but not exclusively, honorific) can tell us about the expression of collective ethnicity.

In the ancient Greek world, statements of identity - both within and between communities - were frequently underscored by a rhetoric which highlights the existence of shared practices or customs. This principle was expressed in the message of the Athenians to the Spartans when dissuading

to discuss this topic in Paris at a DIKTYNNA workshop in December 2015. I benefitted greatly from discussion at both events and also from conversation with Michael Metcalfe on the subject of early Hellenistic Ionia.

Abbreviations used:

I. Didyma: A. Rehm and R. Harder (eds.) Didyma II. Die Inschriften (Berlin: Deutsches Archäologisches Institut, 1958);

I. Erythrai: H. Engelmann, Die Inschriften von Erythrai und Klazomenai, I-II (Bonn: R. Habelt, 1972-3);

IG: Inscriptiones Graecae (Berlin: Berlin Academy, 1873-);

ML: R. Meiggs and D. Lewis, A Selection of Greek Historical Inscriptions to the End of the Fifth Century BC. Revised Edition (Oxford: Oxford University Press, 1988);

RO: P.J. Rhodes and R. Osborne, Greek Historical Inscriptions 404-323 BC (Oxford: Oxford University Press, 2003);

OR: R. Osborne and P.J. Rhodes, Greek Historical Inscriptions 478-404 BC (Oxford: Oxford University Press, 2017);

SEG: Supplementum Epigraphicum Graecarum (Leiden: Brill, 1923-);

Welles: C. Bradford Welles: Royal Correspondence in the Hellenistic Period. A Study in Greek Epigraphy (Prague: Kondakov Institute; New Haven: Yale University Press, 1934).

All ancient dates are BC unless stated.

2 M. Ehala, Signs of Identity: The Anatomy of Belonging (London and New York: Routledge, 2017).

3 See, for instance, S. Alcock, Archaeologies of the Greek Past: Landscape, Monuments, and Memories (Cambridge: Cambridge University Press, 2002); J.M. Hall, Ethnic Identity in Greek Antiquity (Cambridge: Cambridge University Press, 1997); J.M. Hall, Hellenicity. Between Ethnicity and Culture (Chicago and London: University of Chicago Press, 2002); J.M. Hall, 'Ancient Greek ethnicities: towards a reassessment', Bulletin of the Institute of Classical Studies 58 (2015), pp. 15-29; J. Skinner, The Invention of Greek Ethnography: From Homer to Herodotus (Oxford: Oxford University Press, 2012); J. McInerney (ed.), A Companion to Ethnicity in the Ancient Mediterranean (Oxford: Blackwell, 2014); K. Vlassopoulos, 'Ethnicity and Greek history: re-examining our assumptions', Bulletin of the Institute of Classical Studies $5^{8}$ (2015), pp. 1-13. 
them from accepting terms with Xerxes: 'There is the phenomenon of being Greek (to Hellenikon): sharing blood and speaking one language, with temples to the gods and religious rites in common and a shared way of life' (Hdt. 8.144.2).

In this Herodotean view, the three practices identified as unifying the Greeks are language, religious rites and the way of life; indeed, modern analyses have identified practices (in the sense of individual and shared actions) as one way in which groups create cultural identity. ${ }^{4}$ When we move into polis-level rhetoric, we encounter claims made about the significance for collective identity of practices involving the return of favours by way of honorific recognition. Over the course of his argument that the Athenians should revoke Leptines' law abolishing honorific exemption from taxes (ateleia), Demosthenes claimed that Athenian honorific inscriptions were a memorial of the city's character

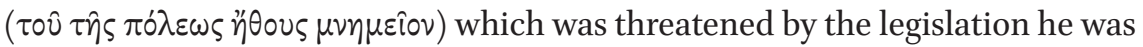
challenging (Dem. 20.64). Elsewhere in the same speech Demosthenes promoted the idea that the return of good favours was an element of Athenian character (20.11-12). Demosthenes, of course, was aiming to persuade an audience of Athenians into voting against Leptines' law by drawing them into a web of beliefs about the distinctively Athenian nature of its honorific system. But as we shall see over the course of this paper, claims about the practice of euergetic reciprocation were deployed not only to strengthen inward-facing bonds of collective identity, but also to foster links with the outside world.

In this paper I explore the role played by accounts of the honorific system and the rhetoric of reciprocity in a remarkable historical phenomenon: the persistence of polis-identity and polis-institutions of small- and mediumsized Greek city-states in the Hellenistic period. To this end I will focus upon the Ionian city of Erythrai in the fourth century and early Hellenistic period, though my conclusions are foreshadowed by analysis of the fifth-century epigraphical legacy of the city. Extant classical literature, as is well known, is Athenocentric; accordingly, in order to get a sense of the nature of the rhetoric of honorific practice beyond Athens, it is necessary to look at the evidence of inscriptions and the language that they use. ${ }^{5}$ For Erythrai, such a line of

4 For the 'cultural practice' approach to identity, see H. Tajfel (ed.), Social Identity and Intergroup Relations (Cambridge: Cambridge University Press, 1982); G.C. Bentley, 'Ethnicity and Practice', Comparative Studies in Society and History 29 (1987), pp. 24-55; S. Jones, The Archaeology of Ethnicity. Constructing Identities in the Past and Present (London and New York: Routledge, 1987); the critique of Hall, Hellenicity, pp. 21-2, distinguishes cultural from ethnic identity. On the significance of the invention of traditions about collective practices, see E. Hobsbawm and T. Ranger (eds.), The Invention of Tradition (Cambridge: Cambridge University Press, 1983).

5 Cf. I. Savalli-Lestrade, "Remarques sur les "grandes" et les "petites" cités aux époques classique et hellénistique d'après les sources littéraires et épigraphiques', in Actes du II ${ }^{e}$ Atelier DIKTYNNA (Paris, ANHIMA, 19/11/2011), Topoi 18 (2013), pp. 117-29. 
research is made possible by the two-volume publication of Die Inschriften von Erythrai und Klazomenai of $1972-3$ (henceforth, I. Erythrai), ${ }^{6}$ which preserves a sufficient concentration of inscribed documents to allow us to probe into the expressions of identity of the community of Erythraians in the classical and Hellenistic period. ${ }^{7}$ This epigraphical record enables a view into the ways in which such communities used rhetoric to meet the political realities of the Hellenistic period. The question of audience and readership of inscriptions is pertinent to this analysis, but even if we envisage that inscriptions were not read closely, ${ }^{8}$ it is safe to assume that epigraphical publication - which habitually presented its decrees as the consensus of a democratic community or a polis - was a medium through which the collective identity of the communities and their institutions was publicly enunciated and promoted through language.

The perspective that rhetoric plays a role in supporting and nurturing institutions is one which has resonance with some contemporary theoretical perspectives. In the field of comparative institutional analysis, some scholars see institutions as defined by rules, formal or informal, which provide stability and meaning to an entity, and which are the product of the historical aggregation of multiple human actions. ${ }^{9}$ Recent work in the field of New Institutionalist analysis has developed the view that institutions might be

6 The inscriptions are published on the Packard Humanities Institute website (https://inscrip tions.packhum.org), but the online version uses a different system of numeration.

7 Notices of inscriptions published since the appearance of I. Erythrai appear in subsequent volumes of $S E G$.

8 Against the view that public inscriptions were closely read, see R. Thomas, Oral Tradition and Written Record in Classical Athens (Cambridge: Cambridge University Press, 1989), pp. 35, 41; for the argument that the Athenians did in fact read their inscriptions, see R. Stroud, The Athenian Grain Tax Law of $374 / 3$ BC. Hesperia Supplement 29 (Princeton, NJ: American School of Classical Studies at Athens, 1988), pp. 46-7; M. Gagarin, Writing Greek Law (Cambridge: Cambridge University Press, 2011), pp. 67-92. J. Shear, Polis and Revolution. Responding to Oligarchy in Classical Athens. Cambridge: Cambridge University Press, 2011), pp. 3-14 argues convincingly that reading was important for the commemorative function of inscriptions.

9 D.C. North, Institutions, Institutional Change and Economic Performance (Cambridge: Cambridge University Press, 1990), p. 3: 'Institutions are the rules of the game in society'; cf. North, Institutions, pp. 36-53; R.L. Jepperson, 'Institutions, Institutional Effects, and Institutionalism', in W.W. Powell and P.J. DiMaggio (eds.), The New Institutionalism in Organizational Analysis (Chicago and London: University of Chicago Press, 1991), pp. 143-63, p. 145 argues that the word 'Institution' 'represents a social order or pattern that has attained a certain state or property' which 'when chronically reproduced, owe their survival to relatively self-activating social processes'. Jepperson 'Institutions', p. 149 writes that 'institutions are socially constructed, routinely-reproduced (ceteribus paribus), program or rule systems'. See also, on institutional perspectives, M.-L. Djelic, 'Institutional perspectives: working towards coherence or irreconcilable diversity?' in G. Morgan, J.L. Campbell, C. Crouch, O. Kaj Pedersen, and R. Whitley (eds.), The Oxford Handbook of Comparative Institutional Analysis (Oxford: Oxford University Press, 2010), pp. 1-40, p. 33. 
grounded also in narratives and discourse ${ }^{10}$ and that discourses are an important way of the exchange and reproduction of ideas and practices: ${ }^{11}$ we shall expand upon these perspectives, in the Erythraian context, over the course of this paper, by proposing that institutional narratives and discourses contribute to the promotion of collective identity.

Within the Hellenistic Greek city, one prominent system of institutional morality which appears to have been habitually reproduced - through the medium of public epigraphy - was that by which communities made public declarations of euergetai ('benefactors'), honouring them with crowns, statues or other privileges. At Erythrai there is evidence for this institution stretching from the early fourth century until the third century AD. ${ }^{12}$ I suggest that the epigraphically-expressed rhetoric of such practices was central to the Erythraians' publicly-enunciated identity and was significant in terms of the institutional survival of their polis. Accounts of honorific grants starting from the fourth century and with increased frequency during the Hellenistic period - were enunciated in decrees as a way of appealing to those with resources; this audience included both members of the community and those outsiders identified as potential supporters of the community's interests. This article engages with the themes of this collection of papers by combining a chronological survey of what can broadly be characterised as public inscriptions (see Appendix, passim) with discussion of specific texts; it attempts to draw out their implications for an understanding of the deployment of the rhetoric of collective identity. The methodological challenge of this approach must be acknowledged: any perspectives that arise are likely to be conditioned by the vagaries of survival, discovery and publication; the language of these

10 J.G. March and J.P. Olsen, 'The New Institutionalism: organizational factors in political life', American Political Science Review 78 (1984), pp. 734-49; V. Lowndes and M. Roberts, Why Institutions Matter: The New Institutionalism in Political Science (Basingstoke: Macmillan, 2013).

11 V.A. Schmidt, 'Discursive Institutionalism: the explanatory power of ideas and discourse', Annual Review of Political Science 11 (2008), pp. 303-26; V.A. Schmidt 'Taking ideas and discourse seriously: explaining change through discursive institutionalism as the fourth New Institutionalism', European Political Science Review 2 (2010), pp. 1-25.

12 At Erythrai, the practice of granting honours is first attested in 394 with the award for Konon (I. Erythrai 6); the longevity of the practice is suggested by the evidence of honours for agoranomoi ('market officials') from the imperial period (I. Erythrai 104-5) and those for Romans dated to the second and third centuries AD (I. Erythrai 63-4). On the role of agoranomoi, see now A. Bresson, The Making of the Ancient Greek Economy: Institutions, Markets, and Growth in the City-States (trans. S. Rendall) (Princeton: Princeton University Press, 2016), pp. 239-42, 246-50; L. Capdetrey and C. Hasenohr (eds.), Agoranomes et édiles. Institutions des marches antiques (Paris: Ausonius, 2012). 
documents is often quite concise and reductionist, making the extraction of ideas about identity quite challenging. Moreover, we must bear in mind that the results of such a survey reflect on epigraphical rather than decree-making practice, which means that our conclusions must pertain very much to the question of the relationship between the expression of identity and the 'epigraphical habit'.

Erythrai appears to have been one of the more prominent Ionian cities of the west coast of Asia Minor during the archaic and classical periods, ${ }^{13}$ the survival of a relatively large number of classical public inscriptions - more than other cities of the same area - is a reflection of this. ${ }^{14}$ This is what makes it an ideal case-study for the assessment of the proliferation of polis-identity in the Hellenistic period, though some of the traits that it exhibits (publishing honorific inscriptions for both insiders and outsiders) are shared with other Hellenistic cities. It is possible to identify three streams in Erythraian public epigraphy in the era before Alexander the Great: inscribed directives concerning secular matters, inscriptions with religious significance, and third, honorific decrees; I shall focus upon the first and third categories over the course of this paper. ${ }^{15}$

13 Erythrai was described as 'the most powerful of the Ionians' (Plu. Mor. 244f) at the time of their war with the Chians (probably in the late sixth century: Hdt. 1.18.3) and 'most zealous' (254c) during their war with the Naxians. The size and population of the city are generally thought to have been substantial: L. Rubinstein, 'Ionia', in M.H. Hansen and T.H. Nielsen (eds.), An Inventory of Archaic and Classical Poleis (Oxford: Oxford University Press, 2004), pp. 1053-1107, p. 1073 and M.H. Hansen, The Shotgun Method. The Demography of the Ancient Greek City-State Culture (Columbia and London: University of Missouri Press, 2006), pp. 105 and 115 designate it as a 'size 5' polis, whose walls enclosed 135 hectares. The fact that Erythrai paid between 7 and 12 talents' tribute per annum in the fifth century, the highest of any Ionian city (G. Bean, Aegean Turkey. An Archaeological Guide (London: Benn, 1966), p. 154; cf. Rubinstein, 'Ionia', p. 1074) has been used to estimate its wealth and population: E. Ruschenbusch, 'Tribut und Burgerzahl im ersten athenischen Seebund', ZPE 53 (1983), pp. 125-43, p. 143 suggests a population of 5600 adult males. However, L. Nixon and S. Price, 'The size and resources of Greek cities', in O. Murray and S. Price (eds.), The Greek City from Homer to Alexander (Oxford: Oxford University Press, 1990) pp. 137-70 dispute Ruschenbusch's methodology, suggesting that calculations based on Erythrai's relatively large contribution of phoros exaggerate the size of the population. Its wealth was based probably on trade (Bean, Aegean Turkey, pp. 137, 155).

14 For the numbers of Erythraian public documents, see Appendix 1. They amount to substantially more than those for any other Ionian city: see P.J. Rhodes with D.M. Lewis, Decrees of the Greek States (Oxford: Oxford University Press, 1997), pp. 355-97.

15 The first of these two categories are, of course, neither exhaustive nor mutually-exclusive. 


\section{Institutional Authority as Identity}

In the classical Greek world, individual poleis possessed their own constitutions and laws; accordingly the rhetoric that surrounded institutions potentially served as an expression of collective identity: inscribed laws and decrees presented themselves as decisions taken on behalf of a consensus of polis-institutions. ${ }^{16}$ As we turn attention first to the inscribed directives (Appendix Tables 1 and 2), ${ }^{17}$ we note that the earliest three Erythraian public documents (I. Erythrai 2, 1, 17) - perhaps produced at a time of Athenian hegemony and under Athenian influence -18 share a concern with the regulation of magistrates or restrictions on office-holding. ${ }^{19}$ They suggest an emphasis on collective law-abidingness in fifth-century Erythrai; this becomes particularly clear in the directive protecting constitutional arrangements as it outlines the procedures concerning the trial of a magistrate who has been prosecuted for violating a law:

16 On consensus-attainment in ancient Greek politics, see M. Canevaro, 'Majority rule vs. consensus: the practice of deliberation in the Greek poleis', in M. Canevaro, A. Erskine, B. Gray and J. Ober (eds.), Ancient Greek History and Contemporary Social Science (Edinburgh: Edinburgh University Press, 2018), pp. 101-56.

17 Owing to the lack of space in the current publication, we set aside detailed discussion of the religious enactments of the city-state (see Appendix Table 2).

18 Fifth-century Athenian regulations concerning the Erythraians: $I G \mathrm{I}^{3} 14$ (I. Erythrai $4=$ OR 121, the famous 'Erythrai decree'), 15 (I. Erythrai 5: concerning the stationing of an Athenian garrison and inspector), and possibly 16 (cf. ML p. 94 and oR p. 116; concerning phrourarchoi) with G. Malachou, 'A second facsimile of the Erythrai Decree (IG $\mathrm{I}^{3}$

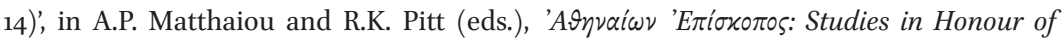
Harold B. Mattingly (Athens: Epigraphical Society, 2014), pp. 73-95 and A. Moroo,

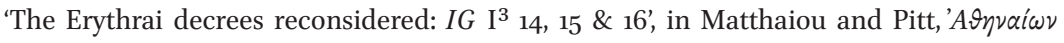

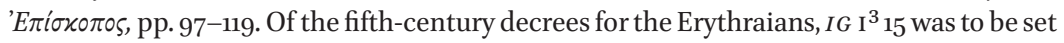
up at Erythrai on the acropolis (line 27). Fourth-century Athenian intervention (after an appeal by Erythraian ambassadors): SEG XXVI $1282=$ RO 17, with S. Hornblower, Mausolus

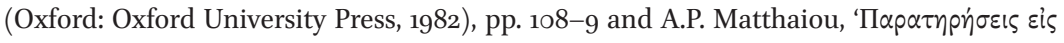

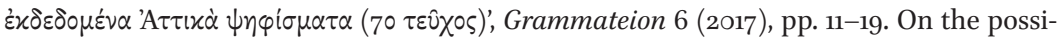
bility of Athenian influence on Erythraian classical institutions, see D.M. Lewis, Selected Papers in Greek and Near Eastern History, edited by P.J. Rhodes (Cambridge: Cambridge University Press, 1997), pp. 51-59; P. Liddel, 'Epigraphy, legislation, and power within the Athenian empire', Bulletin of the Institute of Classical Studies 53 (2010), pp. 99-128, p. 117; see also M. Simonton, 'The Local History of Hippias of Erythrai: Politics, Place, Memory, and Monumentality,' Hesperia 87 (2018), pp. 497-543, pp. 510-12 and 535 .

19 For the possibility that the prohibition of holding the office of secretary to a city-official more than once was a regulation that may have been influenced by Athenian practice, see S. Dmitriev, City Government in Hellenistic and Roman Asia Minor (Oxford and New York: Oxford University Press, 2005), pp. 31, 32, 75 with I. Erythrai 1 lines 1-5. 


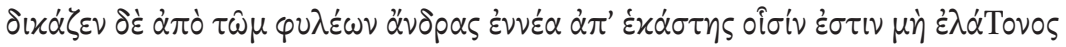

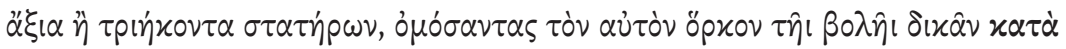

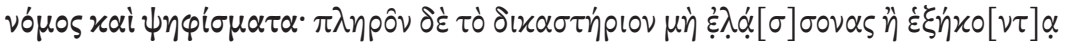

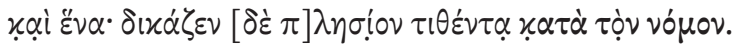

Judgement shall be given by nine men from each of the tribes, who have property worth not less than thirty staters, swearing the same oath as the council, to judge in accordance with the laws and decrees. The court shall be convened by not fewer than sixty-one men: they shall judge having placed it (?the law?) nearby, ${ }^{20}$ in accordance with the law.

I. Erythrai 2 (= OR 122) A lines 13-27; cf. B 18-20); trans. OR 122, adapted

This and two other inscribed documents outline a range of sanctions, including fines (I.Erythrai 1 lines 12-13; 2 A 4-5, 9-10, 22-5; 17.5-18), atimia (disenfranchisement: 1 line 12), legal procedure (2 lines 5-22, 3 lines 8-10) and enforcement by magistrates ( 1 lines 13-15; 2 lines 27-31); they demonstrate the significance of the use of oath (2 lines 18-22) and the putting of proposals to the vote (I. Erythrai 1 lines 10-11). Overall, they are concerned with legal and constitutional bureaucracy, but make no substantive statements about the identity of the Erythraian community or its polis: they say little about the authority that enacted the inscribed arrangements. ${ }^{21}$ Yet regardless of the anonymity of these enactments, the writing down on stone of such regulations represents a process that not only aspires to the communication of instructions to a collective audience, but also is one which makes their directives regular and publicly formulates institutional authority: by this line of reasoning, epigraphical publication itself plays an important role in the formation and development of institutions; these institutions are ones that underscore collective identity, though one that was perhaps not as strongly enunciated as that which we see from the end of the fourth century вс. It is possible that the invisibility of explicitly Erythraian polis-identity in their fifth-century inscriptions was a reflection of their subordinate position in the hegemonic Athenian Empire (see above, note 18). The tendency to inscribe documents pertaining to

20 If this translation is correct, the law is placed nearby the court where the case is judged (as Osborne and Rhodes (oR, p. 123) suggest); it may have been written upon a wooden board, which would have been a more mobile format than a stone stele.

21 Indeed, the identity of the Peproioi of $I$. Erythrai 17 lines 15-16 is unresolved; they seem to be the controllers of swamp-lands; cf. N. Jones, Public Organization in Ancient Greece. A Documentary Study (Philadelphia: Memoirs of the American Philosophical Society, 1987), pp. 304-5. 
the regulation of the work of magistrates and the imposition of fines continues at Erythrai into the fourth century: it is illustrated in I. Erythrai 15 (regulating the sale of wool and the conduct of civic magistrates) and I. Erythrai 10 (recalling exiles and establishing an amnesty). Once again, neither of these texts mentions the community of Erythraians: their rhetoric is technical and pertains to specific situations.

\section{3}

Encouraging Benefaction: Honorific Decrees

At this point we turn to the honorary decrees of the classical period (see Appendix Table 3) with a view to their rhetoric on the formulation of collective identity. It is possible to discern an emphasis on the passing of honours for influential foreigners: in the early and mid fourth century, the Erythraians, under an administration that appears to have moved from democracy to oligarchy, honoured those - Conon the Athenian and two Carian (Hekatomnid) dynasts (Mausolus and Idrieus) ${ }^{22}$ - who were in a position to do things in their interests (I. Erythrai $6=$ RO 8; I. Erythrai $8=$ RO 56; SEG XXXI 969); in the case of the Hekatmonids, the rewards were explained on the grounds that the hon-

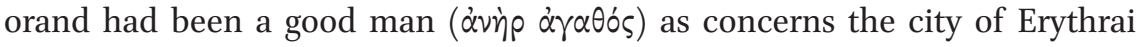
(I. Erythrai 8 = RO 56 lines 3-5; SEG XXXI 969 lines $\left.5^{-6}\right) .{ }^{23}$ Unlike the earlier inscribed regulations, they leave us with little doubt about the Erythraian identity of the body making the honours, each of them mentioning 'the Erythraians' or 'the city of the Erythraians', a choice of expression which may reflect the constitutional arrangements of the time, ${ }^{24}$ or perhaps even the termination of Athenian hegemony. What is significant for our purposes is that in the case of an honorific decree, the statement of the identity of the

22 On Hekatomnid influence over the Erythraians, see Hornblower, Mausolus, pp. 107-10. For the possibility that the Hekatomnids physically moved the site of Erythrai during the fourth century, see Hornblower, Mausolus, p. 110.

23 On the language of approbation in Athenian honorific decrees, see D. Whitehead, 'Cardinal virtues: the language of public approbation in democratic Athens', Classica et Mediaevalia 44 (1993), 37-75.

24 Conon was described as euergetes and proxenos specifically of the Erythraians (I. Erythrai 6 lines 3-4), perhaps suggesting a democratic constitution; the decree for Mausolus describes him as euergetes, proxenos and citizen of the city (I. Erythrai 8 lines $5^{-6}$ ), suggesting a non-democratic constitution; cf. Rо p. 266. For a brief survey of Erythraian democracy and upheaval related to constitutional change, see Rubinstein, 'Ionia', pp. 1074-75; D. Teegarden, Death to Tyrants! Ancient Greek Democracy and the Struggle against Tyranny (Princeton and Oxford: Princeton University Press, 2014), p. 142. See also Simonton, 'The Local History', pp. 510-29. 
community making the grant (sc. the city or the people of Erythrai) was an important aspect of the transaction for it to have the desired effect of gratifying the honorand, corroborating his connection with the awarding community and incentivising readers of the inscription to emulate his behaviour towards the Erythraians.

From the surviving evidence, Erythraian inscriptions of the fourth century appear not to epigraphically document interaction with what might be thought of as peer polities, by which I refer to other city-state communities of the Asia Minor sea-board or beyond; ${ }^{25}$ epigraphical publication tends to commemorate their dealings with more substantial political entities. ${ }^{26}$ But in the late 33 Os BC a new power came onto the scene as the Macedonians arrived in Ionia: according to Arrian, in 334, after the battle of Granikos and his march on Ephesos, Alexander ordered oligarchies to be overthrown and democracies to be established in Ionian cities, the restoration of laws and the remit of tribute that they had paid in previous times to the 'barbarians' (Anab. 1.18.2). Under the influence of the Diadochi in the Hellenistic period, the city appears to have flourished ${ }^{27}$ Erythraian epigraphical publication appears to focus yet more intensively upon the rhetoric of honours, and for the first time we start to see awards being granted to Erythraians (Table 4). There is also a growing tendency - in tune with wider trends across the Greek world ${ }^{28}$ - to

25 At the same time, external evidence does bear witness to Erythraian relations with 'peer' communities of comparable size: Kallias of Erythrai appears, for instance, on a Chian catalogue of proxenoi from the fourth or early third century BC: W. Mack, Proxeny and Polis. Institutional Networks in the Ancient Greek World (Oxford: Oxford University Press, 2015), pp. 300-30; in the fourth century the Erythraians received proxeny status from Kolophon: Rubinstein, 'Ionia', p. 1075. A proxeny award was made by the Gortynians to an Erythraian and an Iasian in the period 225-200: SEG LVIII 937.

26 Moreover, the inscribed agreement between the Erythraians and Hermias of Atarneus - an agreement which seems to be made on equal terms and mutual promises of assistance also demonstrates the Erythraian tendency to write up on inscriptions dealings with ambitious political entities: I. Erythrai 9 .

27 Hornblower, Mausolus, p. 331 n. 306 takes the view that the proliferation of Erythraian coinage in the Hellenistic period demonstrates its economic prosperity. The distribution of stamped amphorae from Erythrai suggests medium-scale participation in trade networks: T. Panagou, 'Patterns of amphora stamp distribution. Tracking down export tendencies', in E.M. Harris, D.M. Lewis and M. Woolmer (eds.), The Ancient Greek Economy. Markets, Households and City-States (Cambridge: Cambridge University Press, 2016), pp. 207-29, pp. 217-8, 228-9; cf. SEG LXIII 948.

28 On the increased level of detail in honorific decrees from the end of the fourth century вС see N. Luraghi, 'The Demos as Narrator. Public Honors and the Construction of Future and Past', in L. Foxhall, H.-J. Gehrke, N. Luraghi (eds.), Intentional History. Spinning Time in Ancient Greece (Stuttgart: Franz Steiner), pp. 247-63 and P. Low, 'Lives from stone: epigraphy and biography in classical Greece', in R. Fletcher and J. Hanink (eds.), Creative Lives in 
elaborate in more detail the good deeds behind the reward and also the specific intention of the honorific decree. An example that is intermediate (in the sense that it is more detailed than earlier decrees but less than later ones) is the reward for Phanes (presumably of Erythrai) son of Mnesitheos, of the 33 о вс:

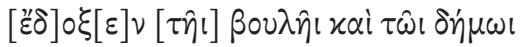

$[\pi \rho \tau \tau \dot{\alpha} \nu] \varepsilon \omega \nu, \sigma \tau p \alpha \tau \eta \gamma \hat{\omega} \nu, \dot{\varepsilon} \xi \varepsilon \tau \alpha \sigma \tau \hat{\omega}-$

$\nu \gamma\left[\nu \omega^{\prime}\right] \mu \eta \cdot \dot{\varepsilon} \pi \varepsilon เ \delta \dot{\eta} \Phi \alpha \nu \hat{\varsigma} \varsigma \mathrm{M} \nu \eta \sigma \theta \theta \dot{0} \circ v$

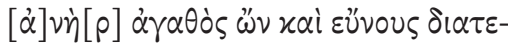

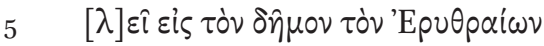

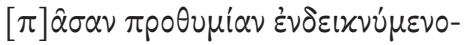

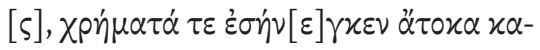

[i] $\varepsilon i \varsigma \tau \tau \dot{\nu} \nu$ है $\alpha \pi \varepsilon \mu \psi \iota[\nu \tau] \omega \hat{\omega} \nu \sigma \tau p \alpha \tau i \omega \tau-$

$[\hat{\omega} \nu] x \alpha i \tau \hat{\eta} \varsigma \dot{\alpha} x \rho \circ \pi \dot{\partial} \lambda \varepsilon \omega \varsigma \tau \dot{\eta} \nu x \alpha \tau \alpha[\sigma]-$

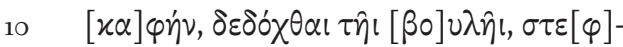

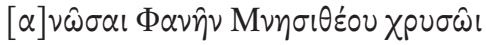

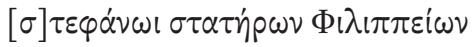

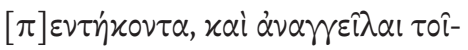

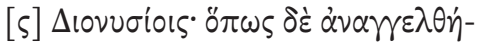

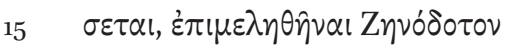

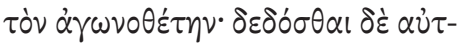

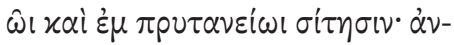

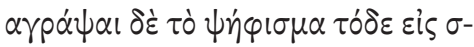

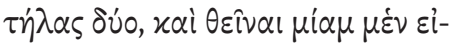

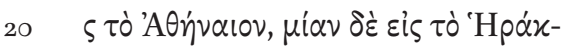

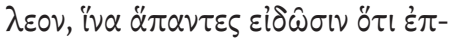

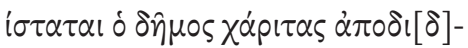

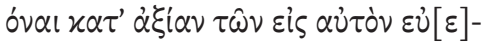

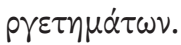

Resolved by the council and the demos. A proposal of the presidents, generals and examiners. Since Phanes son of Mnesitheos is a good man and he acts with goodwill towards the people, showing all willingness (prothymia), and since has given loans without interest for the dispatch of the army for the razing of the acropolis, be it resolved by the council

Classical Antiquity: Poets, Artists and Biography (Cambridge: Cambridge University Press, 2016), pp. 147-74. 
to crown Phanes son of Mnesitheos with a gold crown of 50 Philippeian staters, and to announce it at the Dionysia. The president of the games Zenodotos is to take care of it so that it will be announced; he is to be given maintenance in the office of the presidents. Write up this decree on two stelai, and place one at the sanctuary of Athena, the other at sanctuary of Heracles so that all might know that the demos knows how to repay favours worthily for the benefits conferred on it.

I. Erythrai 21; cf. F. Millar, 'Epigraphy', in M. Crawford (ed.) Sources for Ancient History (Cambridge: Cambridge University Press, 1983), pp. 8o-136, pp. 118-19

The reward of a gold crown was granted for Phanes' ongoing goodwill ( $\varepsilon \ddot{v}$ vov $\delta(\alpha \tau \varepsilon[\lambda] \varepsilon \hat{\imath}$ : lines 4-5) to the demos, but also explicitly because he made interest-free donations both towards the dispatch of soldiers and towards the dismantling of the acropolis when it was held by hostile forces. ${ }^{29}$ Moreover, in this decree we see, for the first time, a hortatory clause in an extant Erythraian decree, which says (lines 21-4) that it is to be set up 'so that all might know that the demos knows how to repay favours worthily for the benefits conferred on it'. Such statements - known initially from Athens and then from elsewhere in the Greek world $-^{30}$ are made also on Erythraian decrees of the third century $\mathrm{BC}$ to varying degrees of detail with broadly similar implications: so that the demos might appear to repay good deeds, or so that others might know that it does so. ${ }^{31}$ This protreptic emphasis of the rhetoric here is, I suggest, in tune with the Erythraians' interest in drawing out the capital of their honorific decrees and shines light upon the collective identity that they wanted to project. It is relevant to our understanding of the dissemination of identity to note that the inscription with this message

29 Presumably, as A.W. McNicoll, Hellenistic Fortifications from the Aegean to the Euphrates. With revisions and an additional chapter by N.P. Milner (Oxford: Oxford University Press, 1997), pp. 64-5 reasons, the acropolis was held by forces rival to the demos of the Erythraians. For inscriptions concerning wall-building, see I. Erythrai 22 and 23.

30 For the hortatory intention in Athenian decrees, see J. Miller, 'Euergetism, agonism, and democracy: the hortatory intention in late classical and early Hellenistic Athenian honorific decrees', Hesperia, 85 (2016) pp. 385-435 and S.D. Lambert, Inscribed Athenian Laws and Decrees in the Age of Demosthenes. Historical Essays (Leiden and Boston: Brill, 2018), pp. 71-89; for its appearance on inscriptions beyond Athens, see W. Larfeld, Handbuch der griechischen Epigrafik. Einleitungs- und Hilfdisziplinen. Die nicht-attischen Inschriften (Leipzig: Beck, 1907), pp. 504-8.

31 I. Erythrai 27 lines 16-20; I. Erythrai 28 lines 48-9; I. Erythrai 35 lines 7-8; I. Erythrai 36 lines 6-7. 
was to be set up at two sanctuaries at Erythrai, where they might be seen by those who visited them.

After Alexander, Ionia was dominated at first by Antigonos, then Lysimachos. In 281 BC, Seleukos' victory and Lysimachos' defeat at the battle of Koroupedion left his family influential over much of western Asia Minor. It seems to have been in this context that a number of exceptionally detailed epigraphic documents were published, probably in the 270 s and 26 os respectively. ${ }^{32}$ Of these, the honorary decree for the benefactor Polykritos (I. Erythrai 28) is, at 52 lines, the longest honorific decree in existence from Erythrai. It states that among Polykritos' motivations was to 'oblige the demos' and to become use-

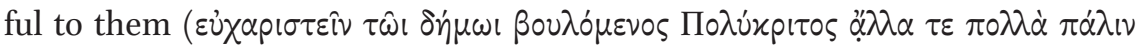
$\chi p \eta \dot{\sigma \mu \rho \varsigma ~ \varepsilon ่ \gamma \varepsilon \nu \eta ं \theta \eta: ~ l i n e s ~ 34-5) . ~ A t ~ l i n e s ~ 48-9 ~ w e ~ r e a d ~ a ~ c l a u s e ~ w h i c h ~ t e l l s ~ u s ~ w h y ~}$ the honours were to be enacted by the Council (boule) and the people (demos) at the Assembly: 'so that the people appears to repay worthy favours done

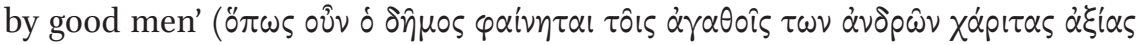

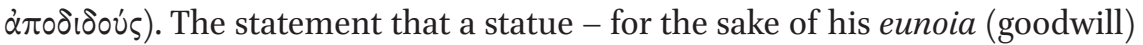

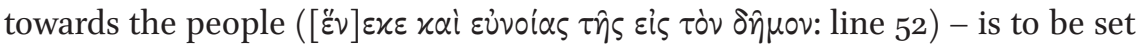
up next to the honours previously written up for him demonstrates, then, that this was not the sole occasion on which Polykritos was honoured with physical commemoration in the city.

So far, therefore, we have seen the Erythraians projecting an image of their community as ready to repay internal benefactors; such a process could have contributed to the bonds between mass and elite within the city and strengthened the whole community's collective identity. But how far was this image projected also to outsiders? This brings us to the exchanges that the Erythraians undertook with the Seleucid monarchs; the evidence consists of an inscribed letter (I. Erythrai 31) and an associated decree (I. Erythrai 30). For the purposes of this paper, I leave untouched the debates about whether these exchanges were undertaken with Antiochos I (281-61) or II (261-46), and follow Welles' view that they pertain to the latter. ${ }^{33}$

32 Documents of interest not discussed here include the honours for Hekatas (I. Erythrai 27, probably of the $270 \mathrm{OS}$, as P. Fröhlich, Les cités grecques et le contrôle des magistrats (IV ${ }^{e_{-}}$ $I^{e r}$ siècle avant J.-C.) (Geneva: Droz, 2004), p. 544 argues), I. Erythrai 29 for the generals, I. Erythrai 114 for Kallikrates. See also Appendix Table 4.

33 Welles, pp. 78-82 prefers Antiochos II; C. Habicht, Divine Honors for Moral Men in Greek Cities: the Early Cases. Trans. J.N. Dillon (Michigan: Michigan Classical Press, 2017), pp. 71-2 prefers Antiochos I. Piejko (cf. SEG XLI 984) associates the letter with Antiochos III. 


\section{The Economy of Goodwill and Gratitude as a Discourse of Identity: The Correspondence with Antiochos}

The fragmentary state of the honorific decree for Antiochos (I. Erythrai 30) means that we cannot be certain about its substance. ${ }^{34}$ But enough remains of the designation B $\alpha \sigma i \lambda \dot{\varepsilon} \alpha$ 'Avtioxov (King Antiochos) in line 20 for us to be relatively confident that it concerns a Seleucid monarch. Significant portions of the decree have been restored on the basis of the text of the extant inscribed letter of Antiochos to the Erythraians (I. Erythrai 31); accordingly, it appears to praise Antiochos and to crown him for the sake of his goodwill (eunoia) towards the people (demos) (lines 20-2). Noteworthy too for our understanding of Erythraian attitudes is the plausibly-restored reference to their own

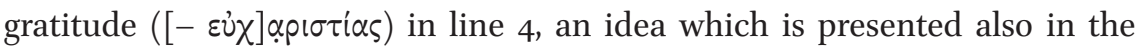
king's inscribed letter as a characteristic of Erythraian behaviour (I. Erythrai 31 lines $7-8,14-5)$.

The inscribed letter (I. Erythrai 31), discovered on the site of Erythrai in the 1870 s, set out a communication from King Antiochos in which he pledged to continue the autonomy and freedom from taxes that the city had enjoyed since the time of Alexander and Antigonos (lines 21-8). The text of the letter, which is substantially intact, appears to have been followed on the stone by a (now highly fragmentary) decree of the Erythraians, presumably one which offered thanks to the Seleucid making the grant. The letter tells the story of ambassadors coming from Erythrai, bringing with them a decree for Antiochos

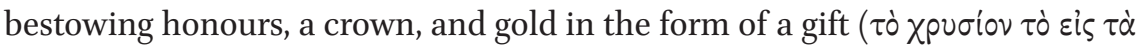
$\xi \dot{\varepsilon} v i \alpha:$ line 5). ${ }^{35}$ According to the narrative presented, the envoys gave an account

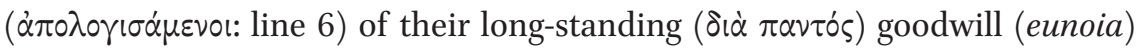
with the royal family (lines 6-7), an account of the gratitude (eucharistia) of the Erythraian multitude (plethos) ${ }^{36}$ which it shows towards all its benefactors (euergetai) (lines 7-9), and the esteem (proagoge) which the city had enjoyed under previous kings (lines 9-10). These claims were used in an appeal to the king that he should be friendly and should promote the interests of the city

34 For Piejko's restorations of I. Erythrai 3o, see SEG XXXVII 923 and XLI 984, taking the view that it was a decree for Antiochos III.

35 On such gifts, in particular those which were used to welcome foreigners to cities, see now A. Cinalli, Tà ̧̧́vıa: la cerimonia di ospitalità cittadina. Studi e Ricerche, 27. Studi umanistici-Antichistica. (Roma: Sapienza Università Editrice, 2015).

36 The term plethos is one that emphasises the multitude of Erythraians offering gratitude; it is to be distinguished in Hellenistic inscriptions from demos, which refers to the people at the assembly. In this case it might be seen as emphasising that the great mass of Erythraians felt gratitude towards the King. 
(lines 10-12). The reported Seleucid response was to accept the awards of the Erythraians, to praise their gratitude (lines 12-5), to remind the Erythraians of the fact that their family had, 'since the beginning', sustained goodwill towards their community (lines 15-6): goodwill (eunoia), it seems, was a common currency in the exchange. We read also that the envoys reminded the kings of their autonomy and freedom from tax under Alexander and Antigonos and that the royal ancestors (progonoi) were always zealous towards them (lines 21-4). The king, accordingly, accepted the honours and praised the Erythraians, apparently convinced by the decree delivered to them and the words of the envoys, and pledged to help the city maintain its autonomy and its exemption from taxes.

The Erythraian ambassadors appear, therefore, to have made a wellinformed speech at the court. In this account, the invocation of ideas about goodwill, its reciprocal relationship with gratitude and the past are central to the Erythraian appeal, and characteristic of a certain type of rhetoric of Hellenistic ambassadors, to whom local history was an important tool in the creation of identity, persuasion, and inter-community negotiations. ${ }^{37}$ Invoking an account of a common history was important to the development of a collective identity: we see discourses on, and shared attitudes towards, goodwill and gratitude being used for diplomatic purposes in claims made by cities to Kings (and vice versa), a tendency which we encounter in inscribed correspondence from elsewhere in the Greek world (see Appendix Tables 5 and 6). Such appeals could be based, in both epideictic and persuasive modes, upon the evidence of decrees, and I have listed examples of such claims at Appendix

37 Most recently on appeals to the past made by ambassadors and other representatives of the communities to outsiders in the Hellenistic period, see H.-J. Gehrke, 'Myth, history and collective identity: uses of the past in ancient Greece and beyond', in N. Luraghi (ed.), The Historian's Craft in the Age of Herodotus (Oxford: Oxford University Press, 2001), pp. 286-313; J. Ma, 'Peer polity interaction in the Hellenistic age', Past \& Present 180 (2003), pp. 9-39; A. Chaniotis, 'Ein missverstandenes Ritual der griechischen Diplomatie: Geschichte als Argument', in C. Ambos, S. Hotz, G. Schwedler, S. Weinfurter (eds.), Die Welt der Rituale. Von der Antike bis zur Gegenwart (Darmstadt: Wissenschaftliche Buchgesellschaft Academic, 2005), pp. 106-9; R. Zelnick-Abramovitz, 'Look and listen: history performed and Inscribed', in R. Scodel (ed.), Between Orality and Literacy: Communication and Adaptation in Antiquity (Leiden: Brill, 2012), pp. 175-96; L. Rubinstein, 'Spoken words, written submissions, and diplomatic conventions: The importance and impact of oral performance in Hellenistic inter-polis relations', in C. Kremmydas and K. Tempest (eds.), Hellenistic Oratory: Continuity and Change (Oxford: Oxford University Press, 2013), pp. 165-99. For the polis in Hellenistic rhetoric, see A. Erskine, 'Rhetoric and persuasion in the Hellenistic world: speaking up for the polis', in I. Worthington (ed.), A Companion to Greek Rhetoric (Oxford: Oxford University Press, 2006), pp. 272-85. 
Table $7 .^{38}$ This practice is perhaps to be associated with the tendency during this period for inscribed versions of decrees to become fuller, more substantiated, and to make expressions about their specific intentions. Luraghi has recently argued that in the third century the Athenians introduced historical detail into their honorific decrees when they realised the usefulness of inscriptions as sources for historical narratives; ${ }^{39}$ in the case of Erythrai, we might consider the possibility that increased detail was set out with a view to appealing to future domestic and foreign benefactors. The act of inscribing a decree lodged it in the public memory and would, in due course, have contributed to the reproduction of collective identity.

It is worth reflecting on the claim, put into the mouth of the ambassadors by the writer of the letter, that the Erythraian multitude displays goodwill towards all of its benefactors (lines 8-9). It is, perhaps, just possible to imagine the Erythraian ambassadors making speeches at the court reciting not only their community's goodwill towards the Seleucids but also that towards previous patrons such as the Hekatomnids and the Athenians; whatever the details, they appear to have replayed the history of their city to their patrons as a way of appealing to them for support. ${ }^{40}$

But before we move on we must also remember that in this particular case the inscription - as an inscribed piece of royal correspondence - was written up in the words of the King's letter. And so the account of Erythraian gratitude

38 On the use of decrees in the context of diplomatic appeals, see J.-M. Bertrand, 'Formes de discours politiques: décrets des cites grecques et correspondence des rois hellénistiques', in C. Nicolet (ed.), Du pouvoir dans l'antiquité: mots et réalités (Paris and Geneva: Droz, 199o), pp. 101-15; Rubinstein, 'Spoken words', p. 179; A. Chaniotis, 'Paradoxon, enargeia, empathy: Hellenistic decrees and Hellenistic oratory', in Kremmydas and Tempest, Hellenistic Oratory, pp. 201-16; A. Chaniotis, 'History as an argument in Hellenistic oratory: the evidence of Hellenistic decrees', in P. Derron (ed.), La rhétorique du pouvoir. Une exploration de l'art oratorie délibératif grec (Vandoeuvres: Fondation Hardt Entretiens 62, 2016), pp. 129-74 (especially pp. 152-62 for the 'past services oblige' argument). For the view that the Erythraian ambassadors made references to the past to encourage Antiochos to live up to the generosity of his predecessors, see S. Wallace, 'Alexander the Great and Democracy in the Hellenistic World', in B. Gray and M. Canevaro (eds.), The Hellenistic Reception of Classical Athenian Democracy and Political Thought (Oxford: Oxford University Press, 2018), pp. 45-72, p. 65 .

39 See Luraghi, 'The demos'. Shear, Polis and Revolution and B. Steinbock, Social Memory in Athenian Public Discourse: Uses and Meanings of the Past (Ann Arbor: University of Michigan Press, 2013), pp. 90-4 emphasise the role of inscriptions in the manufacture of public memory in Athens.

40 A restored reference in the classical-period document of Erythrai concerning the cult of

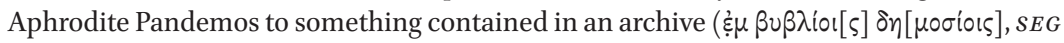
XXXVI 1039 line 18; cf. XXXIX 1238) suggests that a range of such materials might have been available to the Erythraians. 
(charis) and goodwill is given additional authority by the fact it is enunciated in the Royal voice whilst also reminding them that their ambassadors recognised the moral virtues of the Seleucids. This rhetoric of harmony and mutual benefit (as well as collective Erythraian interests), though, may conceal a more complicated set of underlying negotiations that involved self-interest and other factors.

Further honorific decrees of Hellenistic Erythrai are listed in Appendix Tables 4 and $8,{ }^{41}$ but the next document to be discussed offers a slightly different perspective on the Erythraian public rhetoric of identity. An inscription which may, possibly, be contemporary with Antiochos' letter is the stele containing two decrees of the council and people of the Erythraians concerning the repair and maintenance of the statue of Philites the tyrannicide; ${ }^{42}$ the stone was discovered nearby on the island of Chios but a cogent case has been made for its original derivation from Erythrai (I. Erythrai 503$){ }^{43}$

The first of the two decrees, proposed by Zoilos son of Chiades, specifies that bids were to be invited for the restoration of the statue to its condition before the removal of a sword by those serving the oligarchy (hoi en tei oligarchiai: lines 10-4); it added that the market officials (agoranomoi) were to ensure that the statue was free of verdigris and that it be crowned at the time of festivals (lines 14-7). The second decree added that the treasurers of the month were to contribute to the costs incurred by the crowning and polishing of the statue (lines 22-7), but added that in the future the cost of the crowns was to be added to the conditions of the contract sold by the agoranomoi (lines 27-9).

41 For discussion of a third-century decree from Erythrai honouring jury service, see Walser A.V. Walser, 'DIKASTERIA. Rechtsprechung und Demokratie in den hellenistischen Poleis', in C. Mann and P. Scholz (eds.), "Demokratie" im Hellenismus: Von der Herrschaft des Volkes zur Herrschaft der Honoratioren? Die hellenistische Polis als Lebensform, 2. (Mainz: Verlag Antike, 2012), pp. 74-108.

42 It was dated by Engelmann and Merkelbach, on the basis of letter-forms, to the period after the battle of Koroupedion (I. Erythrai 503) of 281; Teegarden, Death to Tyrants!, pp. 153-64 follows this dating. For a date in the middle of the fourth century, based on letter forms, see also Fröhlich, Les cités grecques, pp. 543-4.

43 For the argument that the stele derives from Erythrai, see A. Heisserer, 'The Philites Stele', Hesperia 48 (1979), pp. 281-93, followed by J.P. Gauthier, Les cités grecques et leurs bienfaiteurs. IV ${ }^{e}-I^{e r}$ siècle avant J.-C. (Athens and Paris: French School at Athens, 1985), p. $3^{2}$ and Teegarden, Death to Tyrants!, pp. 142-72. Engelmann and Merkelbach suggest that its place of origin was nearby Klazomenai. 
There have been several explanations of the damage and subsequent refurbishment of the statue, but the implication is that restored democrats blamed the neglect of the statue on a previous regime that it branded oligarchic. ${ }^{44}$ Recently Teegarden suggests that the creation and subsequent manipulation of the statue of Philites played an important role in the foundation, contestation, and ultimate securement of the democracy that was established in Erythrai in the wake of Alexander's conquest of western Asia Minor. ${ }^{45}$ There is certainly an element of politically-motivated ideology behind the proposal to have such a statue repaired. Notably, though, the costs of the activity had evidently to be contracted out to some wealthy bidder who was willing to put forward the money; from the second decree, it appears that in this first year the treasurers of the month were to cover the costs, but there appears to be uncertainty about whether this could happen on subsequent occasions (lines 22-9). There is, in the inscription, then, little convincing indication of community-sponsored democratic partisanship. For one thing, there is no mention of demokratia in the text, though it is a term which is epigraphically represented at Erythrai elsewhere (I. Erythrai 29 line 12). But the motivation of the decree is expressed in the hortatory clause of the first decree, which states that it is to be resolved 'so that it is apparent that the people takes great care and constantly remembers its benefactors

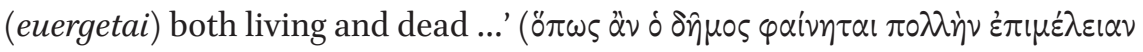

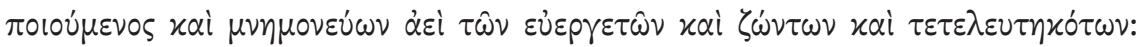
lines 6-9). ${ }^{46}$ As with the honorific material we have looked at, looking to the future and thinking about the appeal to benefactors was the rhetoric being most clearly enunciated in this decree, and it was underscored by an expression of shared identity.

\section{6 The Discourses of Identity in Sub-polis Units: the Phrikyladai stele}

Finally we come to a newly-discovered inscription at the World Museum, Liverpool, in which an association - involving individuals prosopographically attested as from Erythrai - honours officials known as wine-commissioners (oinonai) for their services to the community. Observations have already been

44 Teegarden, Death to Tyrants!, pp. 147-50, discussing a range of interpretations of the decrees.

45 Teegarden, Death to Tyrants!, p. 146; cf. V. Azoulay, Les tyrannicides d'Athènes. Vie et mort de deux statues (Paris: Le Seuil, 2014), pp. 94-6.

46 For a view of the text as essentially commemorative, see Heisserer, 'The Philites Stele', pp. $286-7$, p. 29o, using this point to explain what he thinks of as the abbreviated formulae of the stele. 
made about the similarity of the language of this decree to that of Erythraian public decrees; ${ }^{47}$ the sentiment of reciprocation behind the hortatory clause which states 'so that if anyone else wants to act with philotimia (zeal), they might see that the association (koinon) of the Phrikyladai knows how to pay back due gratitude for those things of which it might be benefitted' ( $00 \omega[\varsigma] \delta$

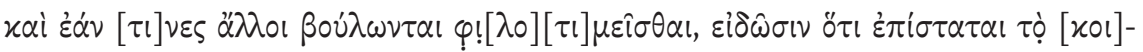

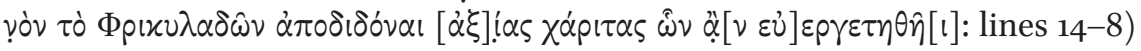
is reminiscent of the types of claim we have already observed in inscriptions associated with the city.

As Taylor and Vlassopoulos have recently observed, ${ }^{48}$ it used to be the case that the flourishing and growing visibility of private associations was seen as a reflection of the crisis and collapse of the polis as an institution in the Hellenistic period. But at third-century Erythrai, we can hypothesise that the rhetoric of honorific culture found expression not only in the community's dealings with the big external powers and in her interactions with local euergetai, but surfaces also in sub-polis communities. And at the same time, it is in this era, that of the successors, that we see the resurfacing of the Ionian League as a political entity, which had texts of honorary decrees (e.g. I. Didyma 1; I. Erythrai 348) and other arrangements (I. Erythrai 16, 504) written up in its constituent cities. ${ }^{49}$ It is clear, then, that the rhetoric of honorific

47 P. Liddel and P. Low, 'An inscribed gnome of the Phrikyladai from the World Museum, Liverpool', Annual of the British School at Athens 110 (2015), pp. 263-84, pp. 268-70.

48 C. Taylor and K. Vlassopoulos, 'Introduction: an agenda for the study of Greek history', in C. Taylor and K. Vlassopoulos (eds.), Communities and Networks in the Ancient Greek World (Oxford: Oxford University Press, 2015), pp. 1-31, p. 17.

49 On the scope and powers of the Ionian League, see M.O.B. Caspari, 'The Ionian Confederacy', Journal of Hellenic Studies 35 (1915), 35, pp. 175-88, pp. 184-8; P. Herrmann,

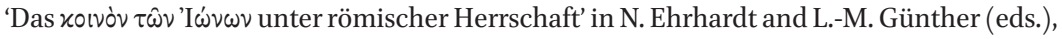
Widerstand - Anpassung - Integration. Die griechische Staatenwelt und Rom. Festschrift für Jürgen Deininger zum 56. Geburtstag (Stuttgart: Franz Steiner, 2002), pp. 223-40, underlining its lack of political significance in the period of Roman rule. For the possibility that it was revived by the Hekatomnids, see P. Debord, L'Asie Mineure au IVè siècle (413-323 a.C): Pouvoir et jeux politiques (Bordeaux: De Boccard, 1999), pp. 176-8. M. Metcalfe, 'Reaffirming Regional Identity. Cohesive Institutions and Local Interactions in Ionia 386-129 BC'. PhD thesis, London University (2005), pp. 102-6 makes the important point that individuals would have made proposals of honours in the Ionian League when they aimed to heighten the honour for a particular individual: decrees of the Ionian koinon had validity in all thirteen members of the league; Metcalfe, 'Reaffirming', p. 194 emphasises also that the association facilitated the existence of regional identity even as conflicts went on between them. On the cult of Antiochos I of the Ionian League, see Habicht, Divine Honors, pp. 66-7. 
culture proliferates among the Ionian communities on at least three different corporate levels: the association, the city and the Ionian League; in all three cases it contributes to the manufacture and reproduction of collective identities.

It seems to be the case that the Erythraian public epigraphical habit became increasingly geared towards the exhibition and reward of euergetic behaviour, and less towards institutional regulation; arguably, this change gives us some insight into the rhetorical expression of the identities of the Erythraians of the early Hellenistic period. So, even when, like other Ionian communities (Klazomenai: I. Erythrai 504) the Erythraians were calling themselves a democracy (demokratia: I. Erythrai 29 line 12) which enjoyed the condition of freedom (eleutheria: I. Erythrai 29 line 13), 50 they were no longer investing in the epigraphical display of regulations, though, as the work of Fröhlich demonstrates, institutions and magistrates continued to play an important role in civic life in this period. ${ }^{51}$

Perhaps it was the case that two centuries of fluctuation between oligarchic and democratic forms of government discouraged them from investing in epigraphically-published accounts of constitutional detail; it may also be the case that, in a political world less polarised by a democratic-oligarchic dichotomy, the Erythraians did not expect their Seleucid overlords, unlike the fifth-century Athenians, to make a connection between the stability of political institutions and the loyalty of their subjects. In other words, geopolitical changes gave rise, at Erythrai, to a shift in the relative prominence of administrative and honorific transactions.

$5^{\circ}$ On claims about demokratia, eleutheria, and autonomia in the Hellenistic period, see W. Grieb, Hellenistische Demokratie. Politische Organisation und Struktur in freien griechischen Poleis nach Alexander dem Grossen. Historia Einzelschriften 199 (Stuttgart: Franz Steiner, 2008), pp. 177-93, 320-34, 36o-78. See now P. Hamon, 'Ungleichheit und Euergetismus: die isotes in den kleinasiatischen Poleis der hellenistischen Zeit', in Mann and Scholz "Demokratie", pp. 56-73, arguing that many cities in the Hellenistic period maintained the type of political institutions which supported democratic equality.

51 For political institutions in Hellenistic Erythrai and the proposal of measures by the strategoi, prytaneis and exetastai; the offices of the agoranomos and agonothetes, financial administration (dioikesis), see Fröhlich Les cités grecques, pp. 135-43, 369-70, 553-6; Dmitriev, City Government, pp. 19, 27-8, 56, 297. 
Honorific transactions, and the discourses of goodwill and generosity in which they were remembered and redeployed, were, we must acknowledge, not the only means by which the Erythraians ensured the security of their polis in the early Hellenistic period: they celebrated the ruler cult ${ }^{52}$ and defended themselves using military means (I. Erythrai 24) and fortifications..$^{53}$ But honorific practices loom large in the epigraphy. As we noted, when we move through the fourth century, the collective identity of the Erythraians becomes more important in their inscribed documents. Perhaps this was because in the Hellenistic period communities needed not only administrative institutions to ensure the existence of their communities, but also strong rhetorical negotiating tools which were supported (and also reproduced) by a sense of collective identity: the Erythraians were ready to deploy narratives about their identity and history of their goodwill and gratitude in appeals to potential benefactors, and they drew on them in order to obtain assistance in maintaining their autonomy (I. Erythrai 31 line 26).

One modernist analysis of institutional competitiveness says that political entities compete by constructing and manipulating institutions in what they perceive to be their best interests; ${ }^{4}$ in the case of Erythrai, we might reasonably assert that the Erythraians expanded the rhetoric of honorific transactions and epigraphical publication as a means - which was in tune with long-standing

52 See Habicht, Divine Honors, pp. 67-72. In the literary record, a passage of Strabo (17.1.43) reports that, according to Kallisthenes in an account of portents that pointed to Alexander's divine roots ( $F G r H 124$ F 14), an Erythraian woman, Athenaïs, who was like an Erythraian sibyl, talked of Alexander's eugeneia. The treatment of Alexander, though, is potentially exceptional, and the authenticity of Kallisthenes' claim not demonstrable. Other examples of ruler cults at Erythrai: I. Erythrai 201 mentions a cult of Alexander; I. Erythrai 64 a priest of Alexander; I. Erythrai 205 lines $74-6$ a cult of Apollo son of Seleukos. Metcalfe, 'Reaffirming', p. 112 suggests that the Erythraians administered the Ionian koinon festival for Antiochos.

53 Investment in fortifications (McNicoll, Hellenistic Fortifications, pp. 6o-6; S. Carlsson, Hellenistic Democracies: Freedom, Independence and Political Procedure in Some East Greek City-States. Historia Einzelschriften 206 (Stuttgart: Franz Steiner, 2010), pp. 116-9). Teegarden, Death to Tyrants!, p. 157 n. 37 collects evidence for wall building in the aftermath of Alexander's conquest. Fortifications of Erythrai are discussed also by Hornblower, Mausolus, pp. 330-1. There was also military resistance and, in 302 BC, the Erythraians were able to prevent the general of Lysimachos, Prepelaos, from taking their city (Diod. Sic. 20.107.5). For the view that fighting was an important expression of identity for Hellenistic cities, see J. Ma, 'Fighting poleis of the Hellenistic world', in H. van Wees (ed.), War and Violence in Ancient Greece (Swansea: University of Wales Press, 200o), pp. 337-76.

54 O.K. Pedersen, 'Institutional Competitiveness: how nations came to compete', in G. Morgan, J.L. Campbell, C. Crouch, O.K. Pedersen, and R. Whitley (eds.), The Oxford Handbook of Comparative Institutional Analysis. Electronic Publication (Oxford: Oxford University Press, 2010), pp. 648-9. 
norms $-^{55}$ of effecting their geopolitical survival and group affiliation. But it would of course be intellectually lazy to accept that this is the only reason why they expressed this rhetoric of political honours epigraphically. Nor must we accept straightforwardly that the Erythraians themselves passed honours simply on the basis of well-informed rational choice. It is likely that behind the epigraphical expression of such rhetoric there was a more complicated web of causation, involving a spectrum of perceived incentives, emotional factors, ${ }^{56}$ aspiration, altruism, and ideas about of past practice, which are elements of what Jon Elster, in his critique of rational choice theory, calls 'collective belief formation. ${ }^{57}$ What we can say is that in the Hellenistic period, the proliferation of awards made by cities and other communities of honours and their epigraphical publication represented an expansion of forms of interaction between weak and the powerful communities. One conclusion to draw is that, therefore, is that of an impression not of innovation in the rhetoric in third-century Erythrai, but of the adaptation and substantiation of an alreadyestablished narrative about Erythraian identity and of euergesia and its consequences; it was something that lies in what Kuba Filonik calls 'the field of ideological manipulation'. As well as reinforcing internal social structures they helped shape the Erythraians' interactions with other, larger, political entities in Western Asia Minor.

We close by returning to the core theme of this collection of papers: identity. The rhetoric which identified the Erythraians as exhibiting worthy gratitude to those who treated them with eunoia was one which was manufactured to appeal to both insiders and outsiders and at the same time promoted the rhetoric of Erythraian polis-identity. As with any other small community in the ancient world, we can never really know what Erythraians thought about their collective identity, but the study of the language of their inscribed public documents may help us realise the deployment of its rhetoric in both domestic and diplomatic contexts.

55 For classical-period claims about how eunoia holds alliances together, see P. Low, Interstate Relations in Classical Greece (Cambridge: Cambridge University Press, 2007) pp. 52, pp. 138-9. For the archaic and classical heritage of euergetism, see M. Domingo Gygax, Benefaction and Rewards in the Ancient Greek City (Cambridge: Cambridge University Press, 2016).

56 Cf. A. Chaniotis, 'Moving stones. The study of emotions in Greek inscriptions', in A. Chaniotis (ed.), Unveiling Emotions: Sources and Methods for the Study of Emotions in the Greek World (Stuttgart: F. Steiner, 2012), pp. 91-129; A. Chaniotis, 'Displaying emotional Community - the epigraphic evidence', in E. Sanders and M. Johncock (eds.), Emotion and Persuasion in Classical Antiquity (Stuttgart: F. Steiner, 2016), pp. 237-62.

57 J. Elster, Explaining Social Behaviour. More Nuts and Bolts for the Social Sciences. 2nd Edition (Cambridge: Cambridge University Press, 2015). 


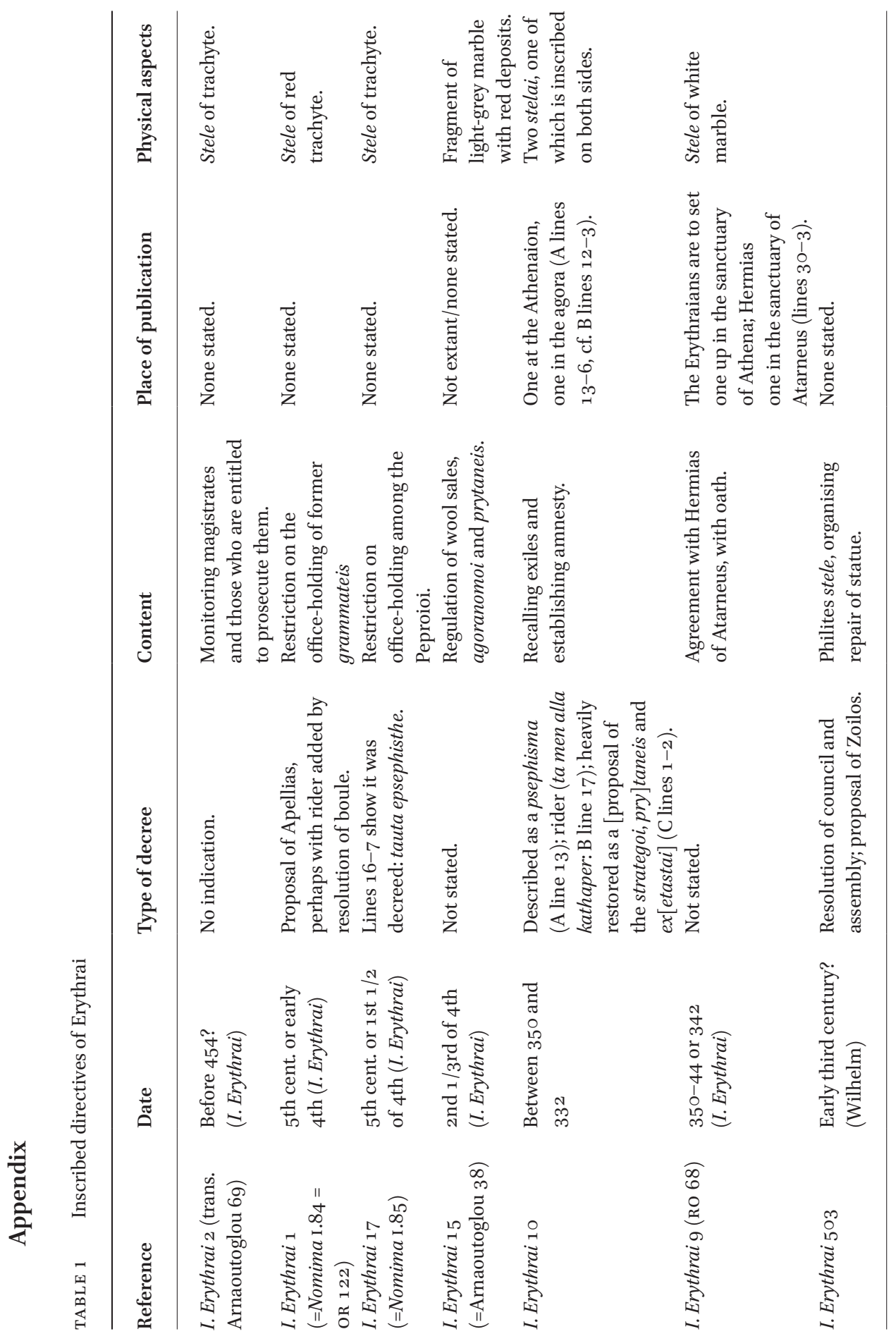




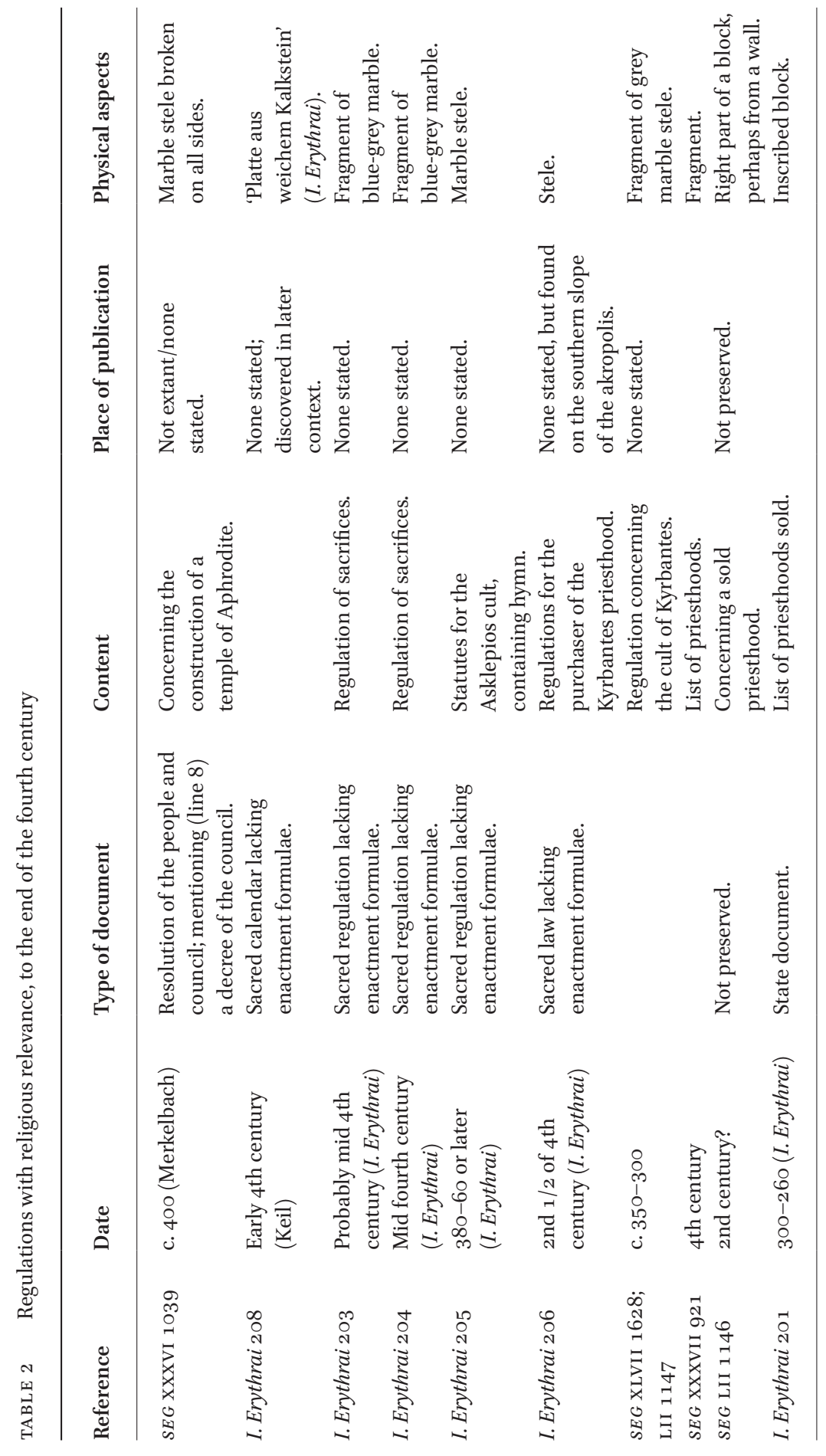




\begin{tabular}{|c|c|c|c|}
\hline Reference & Date & Type of decree & Honorand \\
\hline $\begin{array}{l}\text { I. Erythrai } 6 \\
(=\mathrm{RO} 8)\end{array}$ & $\begin{array}{l}394 \\
\text { (I. Erythrai) }\end{array}$ & $\begin{array}{l}\text { Resolution of } \\
\text { the boule and } \\
\text { the [demos] } \\
\text { (lines } 1-2 \text { ). }\end{array}$ & $\begin{array}{l}\text { Konon of } \\
\text { Athens }\end{array}$ \\
\hline $\begin{array}{l}\text { I. Erythrai } 8 \\
(=\mathrm{RO} 56)\end{array}$ & Mid 35os? & $\begin{array}{l}\text { Resolution } \\
\text { of the boule; } \\
\text { a gnome of } \\
\text { the strategoil } \\
\text { prytaneis (?). }\end{array}$ & $\begin{array}{l}\text { Mausolos of } \\
\text { Mylasa }\end{array}$ \\
\hline
\end{tabular}

$\begin{array}{cll}\text { SEG XXXI 969 Mid 350s } & \begin{array}{l}\text { Resolution } \\ \text { of the boule; }\end{array} & \begin{array}{l}\text { Idrieus of } \\ \text { a gnome of }\end{array} \\ & \text { the strategoi, } \\ & \text { prytaneis and } \\ & \text { epimenioi. }\end{array}$
$\begin{array}{lll}\text { I. Erythrai 11 } & \begin{array}{l}2 \text { nd } 1 / 2 \text { of } \\ \text { 4th century }\end{array} & \text { Fragmentary. Not preserved }\end{array}$

I. Erythrai 12 4th century, Fragmentary. Not preserved probably

before 340

$\begin{array}{ll}\text { I. Erythrai } 13 & \text { 4th or } 3 \text { rd } \\ \text { centuries }\end{array}$

I. Erythrai $14 \quad$ 4th BC

SEG Fourth

XXXVII 922 century?
Awards

Euergesy, proxeny, prohedria, ateleia of all commodities (both for import and export, both in war and peace), citizenship for him and descendant, a [gilded] statue.

Euergesy, proxeny, citizenship, the right to sail in and out both in war and in peace (inviolably and without a treaty), immunity, prohedria, and bronze statues of Mausolos and Artemisia.

Euergesy, proxeny, ateleia from taxation for imports and exports, prohedria, the right to sail in and out both in war and in peace (inviolably and without a treaty), immunity, priority in lawsuits, citizenship and clan-membership for self and descendants.

Right to sail in and out both in war and in peace (inviolably and without a treaty), priority in lawsuits.

Right to sail in and out both in war and in peace (inviolably and without a treaty), priority in dikai, prohedria.

Fragmentary. Not preserved Not preserved.

Fragmentary. Fragmentary Citizenship.

Fragmentary. Not preserved; Proxeny and euergesy and it is a plural citizenship if they wish. award 


$\begin{array}{lll}\text { Deeds } & \text { Intention } & \text { Place of publication }\end{array}$

Not stated.

Being a good man concerning the city of the Erythraians.

Being a good man concerning the city of the Erythraians.

Unknown.

Unknown.

Unknown.

Fragmentary.

Being good men in matters concerning the polis of the Erythraians.
None stated. Statue to be set up

[wherever] Konon [decides]

(lines 15-6). Discovered to

south of Erythrai.

None stated. Stele is to be set up at the

Stele.

Athenaion; the statues at the agora and the Athenaion

(lines 11-9).

None stated. None stated/not preserved.

Not stated/not Not stated/not preserved. Fragment. preserved.

Fragment.

$\begin{array}{ll}\text { Not stated/not } & \text { At the } \\ \text { preserved. } & 8-9) \text {. }\end{array}$

Not preserved. Not stated/not preserved. Fragment of grey limestone.

Fragmentary. Fragmentary.

Fragmentary.

Not preserved. Not preserved. Fragment of stele of blue-grey Erythraian marble. 
TABLE 4 Honorific decrees of Erythrai c. 334-200 BC

\begin{tabular}{|c|c|c|c|c|}
\hline Reference & Date & Type of decree & Honorand & Awards \\
\hline I. Erythrai 21 & $\begin{array}{l}\text { Probably } \\
\text { between } 334 \text { and } \\
332 \text { or post- } 323 \\
(\text { SEG XL 1012) }\end{array}$ & $\begin{array}{l}\text { Resolved by the } \\
\text { council and the people, } \\
\text { a proposal of the } \\
\text { prytaneis, generals and } \\
\text { the exetastai, describes } \\
\text { itself as a decree. }\end{array}$ & $\begin{array}{l}\text { Phanes, son of } \\
\text { Mnesitheus }\end{array}$ & $\begin{array}{l}\text { Gold crown to be } \\
\text { proclaimed at the } \\
\text { Dionysia, maintenance } \\
\text { at the prytaneion. }\end{array}$ \\
\hline I. Erythrai 34 & $\begin{array}{l}\text { Late } 4 \text { th or early } \\
3 \text { rd }\end{array}$ & $\begin{array}{l}\text { Resolved by the boule } \\
\text { and [the demos], } \\
\text { a proposal of the } \\
\text { strategoi, prytaneis and } \\
\text { the auditors. }\end{array}$ & $\begin{array}{l}\text { Telesidromos } \\
\text { Theudoros } \\
\text { Chalkideus. }\end{array}$ & Praise and crown. \\
\hline I. Erythrai 119 & c. 280 & $\begin{array}{l}\text { Described as a } \\
\text { psephisma (lines 7-8). }\end{array}$ & $\begin{array}{l}\text { Honours for } \\
\text { a judge from } \\
\text { Rhodes }\end{array}$ & $\begin{array}{l}\text { Statue, announcement } \\
\text { at the Dionysia and } \\
\text { Seleukeia. }\end{array}$ \\
\hline $\begin{array}{l}\text { I. Erythrai } 24 ; \\
\text { cf. } s E G \text { XXXIX } \\
1239\end{array}$ & c. $277 / 275$ & $\begin{array}{l}\text { Resolved by the people; } \\
\text { a proposal of Polykritos. }\end{array}$ & $\begin{array}{l}9 \text { named } \\
\text { generals }\end{array}$ & $\begin{array}{l}\text { Gold crown, } \\
\text { [prohedria in all } \\
\text { games], proclamation. }\end{array}$ \\
\hline SEG XXXVII 935 & Third century? & $\begin{array}{l}\text { Enacted by the } \\
\text { [demos]; a gnome of the } \\
\text { [general, prytaneis and } \\
\text { auditors]. }\end{array}$ & Generals & \\
\hline
\end{tabular}

$\begin{array}{ll}\text { I. Erythrai } 27 & \text { c. } 274 \\ & \text { (I. Erythrai); } \\ & 270 \text {, as Fröhlich } \\ & 2004: 544 .\end{array}$

$\begin{array}{ll}\text { I. Erythrai } 28 & \text { c. } 275\end{array}$

SEG XXXIII 963
Enacted by the bo[ule

and the demos];

proposal of [Aristokl]-

es son of Adeimant[os]

calls on the demos to

resolve the decree.

The boule and demos

are to resolve it

(lines 49-5o).

Perhaps two decrees, the second of which is restored as an enactment of the boule and demos.
Hekatas son of Gnotos (also honoured in I. Erythrai 24); he was the agoranomos (lines 6-7)

Polykritos (proposer of I. Erythrai 24)

Perhaps for Polykritos or his son?
Gold crown, prohedria in the games in which the polis participates; announcement at the Dionysia and the Seleukeia.

Praise, gold crown, a bronze statue, which is to be set up in the agora; contains reference to other awards he received. Statue in the agora. 


\section{Deeds}

Being a good man, and is constantly well-disposed to the demos of Erythrai, contributing money without interest to the sending away of soldiers and the razing of the akropolis.

Good-minded (eunoos) towards the [demos] and the bringing of provisions.

For the sake of his arete and eunoia towards the demos.

Military and financial contributions to the defence of the city.

He was eunoos to the demos and he was good and moderate at a time of need and was appointed agoranomos and he held his office justly and equally and followed the laws.

Detailed military and financial contributions.

Making donation; the demos is described as eucharistos (B line 4).

\section{Intention}

It is inscribed 'so that

all may know that the people knows how to return appropriate thanks for the benefits (euergetemata) conferred on it' (lines 21-4). Not preserved.

None stated. set up [in the ago]ra (lines 1-2). In th[e agora] (line 34).
To be set up in Rhodes; the statue was to be

On two stelai, one at the Athenaion, and the other in the Herakleion (lines 19-21).

Not preserved.

'Colourful limestone' (I. Erythrai).

On a stone built into the city walls of Rhodes.

Fragmentary.

Fragment of grey-white marble.
Not stated, but his previous honours were written up on a stele in the agora (lines 53-4)

Not preserved.
Stele. worthy thanks to good men (lines 48-9).

'[So that the demos] might appear ...' (B line 9).
So that everyone might knows how to repay worthy thanks and on account of the gratitude of the people more might be eager to do us favours (lines 16-20). preserved.

Not stated/none

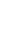


TABLE 4 Honorific decrees of Erythrai c. 334-20о вС (cont.)

\begin{tabular}{|c|c|c|c|c|}
\hline Reference & Date & Type of decree & Honorand & Awards \\
\hline I. Erythrai 29 & c. $270-60$ & $\begin{array}{l}\text { Enacted by the people, } \\
\text { a proposal of the } \\
\text { strategoi, prytaneis and } \\
\text { auditors; the people are } \\
\text { called on to make the }\end{array}$ & Generals. & $\begin{array}{l}\text { Golden crowns; } \\
\text { prohedria in all the } \\
\text { games in which } \\
\text { the city participates. }\end{array}$ \\
\hline
\end{tabular}

$\begin{array}{llll}\text { I. Erythrai3o } & \text { c. 270-6o } & \text { The council and people } & \text { King } \\ \text { (cf. } S E G & & \text { are instructed to } & \text { Antiochos } \\ \text { XXXVII 923) } & & \text { resolve (line 6). } & \text { (II ?). }\end{array}$

\section{Erythrai 31}

c. $270-60$

lines $39-43$.

I. Erythrai 35

Mid 3 rd century

I. Erythrai $36 \quad$ Mid 3 rd century

SEG XXXVII $934 \quad$ 3rd century?
The council and people resolve (line 39); a proposal of the generals, [prytaneis, and auditors].

Resolved by the boule and demos; a proposal of the generals and prytaneis and the auditors. resolution.
King

An[tiochos].

\author{
Neoptolemos \\ son of Physkos \\ of Aetolia, a \\ proxenos and \\ citizen of \\ Erythraians.
}

Timokrates son of Timeas Praise and golden and demos; a proposal of the generals and prytaneis and the auditors.

Describes itself as a decree (line 2), probably of the demos (line 11). of Erythrai.

Not preserved. Not preserved.
[Praise], golden crown, [announcement at the games] (lines 19-22); the crown and a golden gift was to be taken to him by ambassadors (lines 24-5). Not preserved.

Praise and golden crown. 


\section{Deeds}

Intention

Not preserved.

For holding office kalos kai endoxos; they did not submit to danger or fear when the city was at war; contributed zealously by speaking and doing things in the interest of the city, preserving democracy for the people and they handed over the city to their successors free. In return for ensuring that the city was autonomos and aphorologetos (lines 34-5).

Not preserved

Offered advice to the Erythraians about sending an embassy to appeal to the Aetolian league, and assisting the city in resisting the misfortunates; for the sake of his arete and eunoia towards the people (lines 9-10). Speaking and acting in the interests of the city as an ambassador at Delphi; for the sake of his virtue and eunoia towards the people (lines 8-9).

Not preserved.
So that the demos might appear to repay worthy thanks to those who wish to do it good services (lines 18-9).

Not preserved.

So that the demos might be seen to honour those who choose to act favourably towards their city (lines 7-8).

So that the demos might be seen to honour those who choose to act favourably towards their city (lines 6-7)

Not preserved

Place of publication

Physical aspects

Not preserved.

On a block of grey marble.

Not preserved, though there is mention of the sanctuary of Athena (lines 15-16).
Four fragments of a stele of grey Erythraian marble (I. Erythrai).
Not preserved.

At Delphi in the temple of Apollo (lines 10-11).

At Delphi in the temple of Apollo (lines 9-10).

At [a to-be-decided by the people place] (line 7).
From Delphi; discovered in the Polygonal wall.

From Delphi.

Fragment. 
TABLE 4 Honorific decrees of Erythrai c. 334-200 BC (cont.)

\begin{tabular}{|c|c|c|c|c|}
\hline Reference & Date & Type of decree & Honorand & Awards \\
\hline I. Erythrai 76 & $\begin{array}{l}\text { Hellenistic } \\
\text { (I. Erythrai); } \\
\text { perhaps } \\
\text { third century } \\
\text { (prosopography) }\end{array}$ & $\begin{array}{l}\text { Describes itself as a } \\
\text { psephisma. }\end{array}$ & Not preserved. & Not preserved. \\
\hline I. Erythrai 114 & $\begin{array}{l}\text { 3rd century } \\
\text { (I. Erythrai) }\end{array}$ & $\begin{array}{l}\text { Resolution of the boule } \\
\text { and demos; proposal of } \\
\text { the strategoi, prytaneis } \\
\text { and auditors. }\end{array}$ & $\begin{array}{l}\text { Honours for } \\
\text { the judge } \\
\text { Kallikrates son } \\
\text { of Leagoras. }\end{array}$ & Crown (line 28). \\
\hline I. Erythrai 115 & $\begin{array}{l}\text { Hellenistic } \\
\text { (I. Erythrai) }\end{array}$ & $\begin{array}{l}\text { Resolution of the } \\
\text { demos. }\end{array}$ & $\begin{array}{l}\text { Honours for } \\
\text { epistatai. }\end{array}$ & $\begin{array}{l}\text { Crown with foliage at } \\
\text { the Dionysia, } \\
\text { prohedria. }\end{array}$ \\
\hline$S E G$ XXXVII 927 & $3^{\text {rd century? }}$ & $\begin{array}{l}\text { Describes self as a } \\
\text { psephisma (line } 1) .\end{array}$ & $\begin{array}{l}\text { Honours for } \\
\text { an anonymous } \\
\text { judge. }\end{array}$ & Not preserved. \\
\hline $\begin{array}{l}\text { I. Erythrai } \\
43^{1} \text { (cf. } S E G \\
\text { LIII } 528 \text { ) }\end{array}$ & Late 3 rd century & $\begin{array}{l}\text { Resolution of the } \\
\text { [boule }] \text { and demos } \\
\text { (lines } 1-2 \text { ); describes } \\
\text { self as a gnome } \\
\text { pry[taneon....] (lines } \\
5^{-6) .}\end{array}$ & $\begin{array}{l}\text { Honours for } \\
\text { [Eud]oros son } \\
\text { of Glaukos. }\end{array}$ & Not preserved. \\
\hline
\end{tabular}




Deeds Intention Place of publication Physical aspects

Not preserved.

Not preserved.

For serving as a judge.

For eunoia to the demos (line 9). (1)

Perhaps for a public doctor. (lines 1-2).
Not preserved.

The demos is to choose a place (line 29).

'[So that we might be seen to repay the accustomed honours ...]'

Demos is to choose a place; lines $7-8$ suggest that a place 'in front of the stoa [in the agora]' was chosen.

Discovered in Thessaly. Fragment.
Lower fragment of stele.

Two marble slabs. 
- Welles 6 line 10: the Prienians made clear their eunoia to Lysimachos in a decree.

- Welles 11 line 14: Antiochos has given land to Aristodikos of Assos on the grounds of his eunoia and prothymia.

- Welles 13 line 10: Melaeger tells the Ileans that Aristodikos wishes to join their city to the land given him by Antiochos because of the eunoia he has towards them.

- Welles 14 line 10: Kallikrates has written to Ptolemy about the eunoia that the Milesians have towards them.

- I. Erythrai 31: line 6 the Erythraians have offered an account of the eunoia which they have towards the Seleukids; 16 that the Seleukids have entertained eunoia from the beginning to the Erythraians; 32: appears to be a fragmentary reference to the Seleukids' eunoia.

- Welles 25 line 28: Ziaelas of Bithynia responds to the account of eunoia which the people of Cos have given him.

- Welles 31 line 18: Antiochos says that he has had kind feelings to the Magnesians because of the eunoia they have shown towards him and their state on all occasions.

- Welles 45 lines 4 9: Seleukos refers to Aristolochos' eunoia in the award of a bronze statue.

- Welles 52 line 41: Eumenes refers to the fact that the Ionians have spoken a decree declaring the eunoia of the whole people towards him; this is reiterated at line 69 .

- Welles 63 line 8: Opophrenes reports to the Prienians that the envoys have made proofs of their reliability and eunoia on the most urgent of occasions.

- Welles 66 line 11: Attalos III has made awards to Sosander on the grounds of his eunoia and pistis (faith).

- Welles 71 line 6: reference to the ongoing eunoia of the people of Seleukeia to the Seleukids.

TABLE 6 Eucharistia/eucharistos in royal correspondence

- I. Erythrai 31: lines 7-8 Antiochos talks of the eucharistia (gratitude) of the Erythraian people that they have pointed to in requesting the friendship of the king; 14-15 Antiochos praises Erythrai being eucharistoi in every way.

- SEG XXXIII 963: the Erythraian demos is described as eucharistos (B line 4) towards its benefactor.

- Welles 22 line 6: King Seleukos says that his ancestors have given benefactions to Miletos because of their gratitude (eucharistia).

- Welles 52: lines 22 Eumenes talks of the eucharistia of the koinon of the Ionians; and lines 32-6 reports that the Ionian League has urged him, given the eucharistia of the people, to ensure that their interests are promoted. 
TABLE 7 Decrees brought by communities to kings/used in the appeal to kings

- Welles 2 line 12: Eresians are reported to have read a decree to Antigonos.

- Welles 6: line 4 Prienians deliver a decree to Lysimachos; line 9 it announced the goodwill of the people towards the Antigonids.

- I. Erythrai 31: line 3 the Erythraians read a decree containing honours to Antiochos; line 19 Antiochos says that it demonstrates that they are eugenes.

- Welles 31 lines 10, 13: Antiochos refers to the decree which the Magnesians have given to Antiochos about Artemis Leukophrene.

- Welles 32 line 10: ditto.

- Welles 33 line 7: ditto, from Ptolemy to Magnesians.

- Welles 34 line 5: ditto, from Attalos to Magnesians.

- Welles 35 line 4: Theodoros and Amynander to the Teans responding to a decree brought by their envoys.

- Welles $5^{2}$ line 5: Eumenes refers to the decree sent to him by the Ionians.

- Welles 53 I C line 13: Eumenes II acknowledges a letter from the Teans.

- Welles 64 line 3: a king responds to the decree brought by envoys from Nysa.

- Welles 68 line 7: Attalos III responds to a Lydian appeal on the basis of a decree.

TABLE 8 Some other third- and second-century Erythraian honorific decrees

- I. Erythrai 35: Neoptolemos of Aetolia honoured as a proxenos with stele set up at Delphi (third century вс).

- I. Erythrai 111-25: honours for judges both Erythraian and others (second century BC; some, but not all are Erythraian decrees).

- I. Erythrai 431: for a public doctor (late third century вC), discovered in Thessaly.

- Other Hellenistic honours: SEG XXXIII 963 (for Polykritos or his son); XXXVII 922 (proxeny award); SEG XXXVII 933 (for a magistrate); SEG XXXVII 934 and 935 (fragmentary). 